\title{
Multiple Sclerosis Mortality Rates in Canada, 1975-2009
}

\author{
Sharon A. Warren, Wonita Janzen, Kenneth G. Warren, Lawrence W. Svenson, \\ Donald P. Schopflocher
}

\begin{abstract}
Background: This study examined mortality due to multiple sclerosis (MS) in Canada, 1975-2009 to determine whether there has been a change in age at death relative to the general population and decrease in MS mortality rates. Methods: Mortality rates/ 100,000 population for MS and all causes were calculated using data derived from Statistics Canada, age-standardized to the 2006 population. Results: The average annual Canadian MS mortality rate, 1975-2009 was 1.23/100,000. Five-year rates for 1975-79, 1980-84, 1985-89, 1990-94, 1995-99, 2000-04, 2005-09 were: 1.16, 0.94, 1.01, 1.16, 1.30, 1.43, 1.33. Trend analysis showed mortality rates over the entire 35 years were stable (average annual percent change of less than one percent). The average annual 1975-2009 rates for females and males were 1.45 and 0.99. Five-year female rates were always higher than males. Regardless of gender, there was a decrease in MS mortality rates in the 0-39 age group and increases in the 60-69, 70-79, and 80+ groups over time. In contrast, there were decreases in allcause mortality rates across each age group. The highest MS mortality rates for 1975-2009 were consistently in the 50-59 and 60-69 groups for both genders, while the highest all-cause mortality rates were in the 80+ group. Conclusions: Changes in the age distribution of MS mortality rates indicate a shift to later age at death, possibly due to improved health care. However MS patients remain disadvantaged relative to the general population and changes in age at death are not reflected in decreased mortality rates.
\end{abstract}

RÉSUMÉ: Taux de mortalité de la sclérose en plaques au Canada de 1975 à 2009. Contexte : Nous avons examiné la mortalité due à la sclérose en plaques (SP) au Canada entre 1975 et 2009 afin de déterminer s'il y a eu un changement quant à l'âge au décès par rapport à la population en général et une diminution des taux de mortalité due à la SP. Méthode : Les taux de mortalité due à la SP et toutes causes confondues par 100,000 de population ont été calculés d'après les données de Statistique Canada, standardisées pour l'âge de la population en 2006. Résultats : Au Canada, le taux annuel moyen de mortalité due à la SP de 1975 à 2009 était de 1,23/100,000 de population. Les taux quinquennaux de 1975-79, 1980-84, 1985-89, 1990-94, 1995-99, 2000-04 et 2005-09 étaient de 1,16, 0,94,1,01,1,16, 1,30, 1,43 et 1,33 respectivement. L'analyse de tendance a montré que les taux de mortalité pendant cette période de 35 ans étaient stables (pourcentage de changement annuel moyen de moins de 1\%). Les taux annuels moyens de 1975 à 2009 pour les femmes et les hommes étaient de 1,45 et 0,99 respectivement. Les taux quinquennaux des femmes étaient toujours supérieurs à ceux des hommes. Sans égard au sexe, avec le temps nous avons noté une diminution dans les taux de mortalité due à la SP dans le groupe d'âge de 0 à 39 ans et une augmentation dans les groupes de 60 à 69 ans, 70 à 79 ans et 80 ans et plus. Par contre, il y a eu une diminution des taux de mortalité toutes causes confondues dans chacun des groupes d'âge. Les taux de mortalité due à la SP les plus élevés pour la période de 1975 à 2009 étaient invariablement dans les groupes de 50 à 59 ans et 60 à 69 ans chez les deux sexes alors que les taux de mortalité toutes causes confondues les plus élevés étaient dans le groupe d'âge de 80 ans et plus. Conclusions : Les changements par groupe d'âge des taux de mortalité due à la SP indiquent qu'il y a eu une évolution vers un âge plus avancé au décès, possiblement due à une amélioration des soins de santé. Cependant, les patients atteints de SP demeurent désavantagés par rapport à la population en général et les changements dans l'âge au décès ne sont pas reflétés par une diminution des taux de mortalité.

Keywords: aging, epidemiology, multiple sclerosis, mortality

doi:10.1017/cjn.2015.236

Can J Neurol Sci. 2016; 43: 134-141

Multiple sclerosis (MS) is the most common demyelinating disease of the central nervous system. Its cause is not fully understood but thought to be a combination of genetic, immunological and environmental factors. Peak onset age is in the 30's; the disease is associated with relatively long survival and has no known cure. ${ }^{1}$

Mortality rates are useful as an indicator of the burden placed on health care systems by a particular disease. Time trends in mortality rates are interesting for several reasons. It may be possible to draw inferences from them about underlying changes in incidence and possibly clues to etiology. Inferences may also be drawn about the impact of changes in health care. In the past, persons with multiple sclerosis died at notably younger ages than the general population.
Since the 1990s important new treatments, such as disease modifying drugs (DMDs), have been introduced. Their effects might be reflected in decreasing MS mortality rates because patients are living longer to die from other causes. Such mortality patterns can be used to predict the need for future health care services.

From the University of Alberta, Edmonton, Alberta, Canada: Faculty of Rehabilitation Medicine (SAW, WJ), Department of Medicine (KW), and Rehabilitation Research

Centre (DPS). From Alberta Health, Edmonton, Alberta, Canada: Epidemiology and Surveillance Team (LWS).

Received December 8, 2014. Final Revisions Submitted May 5, 2015. Correspondence to: Sharon A. Warren, Faculty of Rehabilitation Medicine, University of Alberta, 3-48 Corbett Hall, Edmonton, Alberta, Canada T6G 2 G4. Email: sharon.warren@ualberta.ca. 
Epidemiological studies based on mortality are subject to limitations, including accuracy of MS diagnosis and completeness of reporting. ${ }^{1}$ However, unlike incidence, mortality figures have been routinely collected by most countries, including Canada, so that they can provide a sufficient number of data points to conduct trend analyses over long periods of time.

Lai et $\mathrm{al}^{2}$ used World Health Organization (WHO) statistics to examine worldwide trends in MS mortality rates for the time period 1965-84 and concluded that there was a general and steady decline in North America and western Europe but a stable or increasing mortality in eastern and northern Europe. A recent study by Ekestern and Lebhart ${ }^{3}$ using government data confirmed variable trends in Europe, but one by Redelings et $\mathrm{al}^{4}$ showed an increasing trend in the United States during the 1990's. We previously reported that Canadian mortality rates fluctuated but remained essentially stable from 1965 to $1994.5^{5}$ The purpose of this study was to update Canadian mortality rates to 2009 to determine whether there are new trends which might reflect changes in health care for persons with MS.

\section{MethodS}

We used mortality data assembled by Statistics Canada provided through the Research Data Centre, University of Alberta. Underlying cause of death is coded by Statistics Canada using the International Classification of Diseases (ICD), for MS 340 (ICD versions 8 and 9) and G35 (ICD version 10); this classification denotes deaths causally related to MS. Population at risk estimates were retrieved from Socio-economic Information Management System (CANSIM) data, Statistics Canada. ${ }^{6}$ Electronic population data was available retroactively until 1971; however we chose to begin our analysis at 1975 so we could subdivide rates by five-year periods. Five-year periods are often used to describe rates with a small number of events in the numerator, such as MS mortality, to smooth out variability in occurrence from one year to another.

Multiple sclerosis mortality rates and $95 \%$ confidence intervals (CIs) per 100,000 population were generated using SPSS version $20 .^{7}$ Multiple sclerosis mortality rates were age-standardized by the direct method based on Poisson approximation for small numbers of events. ${ }^{8}$ All-cause mortality rates were generated using SPSS, age-standardized by the direct method based on binomial variance estimates. ${ }^{8}$ The 2006 Canadian population was used as the standard since it was the most recent.

The 1975-2009 time frame was divided by five-year time periods as follows: 1975-79, 1980-84, 1985-89, 1990-94, 1995-99, 2000-04, and 2005-09. Mortality rates were also divided by age groups of: $0-39,40-49,50-59,60-69,70-79$, and $80+$ years. To examine time trends by geographical region, the Canadian provinces were grouped into four regions: the Western Provinces (British Columbia, Alberta, Saskatchewan, Manitoba), Ontario, Quebec and the Atlantic Provinces (New Brunswick, Nova Scotia, Prince Edward Island, Newfoundland), with the Northwest Territories, Yukon and Nunavut included in the Western Provinces. All cell sizes reported meet the standard for reliable rates $(\mathrm{N}>20){ }^{8}$

Linear trends for rates from 1975 to 2009 were analyzed using the JoinPoint Regression Program ${ }^{9}$ which accommodates small rates based on the Poisson distribution. This program was originally developed for use in cancer epidemiology but it is equally applicable to any condition with small rates. Although mortality rates are shown by five-year time periods in the results, yearly rates were used in the JoinPoint analysis to describe trends over time (and within genders, age groups and regions) to provide the program with 35 data points, because JoinPoint is recommended for use with 10 or more points and we had only seven, five-year periods. The program fits a series of joined straight lines on a logarithmic scale to time points in the annual age-standardized rates (e.g. rates per year). Each joining of a "best fit" straight line to another is called a joinpoint. The number of joinpoints is constrained by the number of total points in the analysis. Each trend line of varying time periods is described by the annual percent change (APC; 2 -sided $t$ test). The average annual percent change (AAPC; 2 -sided $Z$ test) is estimated as a geometric weighted average of the APCs within the entire dataset, accounting for both upward and downward trends. JoinPoint identifies trend lines within an overall time period, in this case 35 years, as well as producing an overall AAPC. The advantage of the AAPC is that it does not assume a linear trend in the data and provides for stable results. ${ }^{9}$ In describing the trend analysis results, the terms "increase" or "decrease" indicate statistical significance $(p<0.05)$, while non-significant results are reported as "stable". The JoinPoint test for parallelism was used to compare female to male trends and trends across geographic regions. Groups are considered similar if the program fails to reject parallelism at $p<0.05$. $^{9}$

\section{Results}

According to Statistics Canada data used for this study, the total number of deaths due to MS from 1975 to 2009 was 10,370 (6,450 females and 3,920 males). The average annual age-standardized Canadian mortality rate due to MS during this time span was $1.23 / 100,000$ population $(95 \%$ CIs $=1.03-1.43)$. The rate for females was $1.45(1.24-1.66)$ and the rate for males 0.99 (0.80-1.17).

Table 1 illustrates the age-standardized, gender-specific and combined average annual MS mortality rates per 100,000 population in Canada by five-year time periods from 1975 to 2009, with the results of the trend analysis. Rates fluctuated within genders over this time period. For both males and females, APC trend lines showed significant decreases in rates through the late 1970s and early 1980s, then significant increases through the 1980s and 1990s. Rates for both genders stabilized in the 2000s. However both male and female rates over the entire 35-year span were essentially stable. Combined mortality rates also fluctuated over the time period 1975-2009, with APC trend lines showing a significant decrease through the late 1970s and early 1980s, a significant increase through the mid-1980s and 1990s, and a significant decrease through the 2000s. Nevertheless the combined mortality rate over the entire 35-year span was essentially stable $(\mathrm{AAPC}=0.04)$. Female mortality rates were consistently and significantly higher than male mortality rates by five-year period, based on the finding that ratio CIs did not include $1 .^{10,11}$ The test of parallelism for the male and female trend lines over the 35 years was not significant however, indicating a consistent spread in the female to male ratios over time.

Figures 1(a) and 2(a) show age-standardized and genderspecific average annual MS mortality rates for each five-year time period from 1975 to 2009 for females and males respectively. 
Table 1: Age-standardized (Canada, 2006), gender-specific and combined average annual MS mortality rates per 100,000 population by five-year periods, 1975-2009 with linear trends.

\begin{tabular}{|c|c|c|c|c|c|c|c|}
\hline Period & $\begin{array}{l}\text { Males Rate/100 } 000 \\
\quad(95 \% \mathrm{CI})\end{array}$ & $\begin{array}{l}\text { Males Linear trend with } \\
\qquad \operatorname{APC}^{a}(95 \% \mathrm{CI})\end{array}$ & $\begin{array}{c}\text { Females Rate/100 } 000 \\
(95 \% \text { CI })\end{array}$ & $\begin{array}{l}\text { Females Linear trend with } \\
\operatorname{APC}^{a}(95 \% \mathrm{CI})\end{array}$ & $\begin{array}{c}\text { Female to Male } \\
\text { Ratio }^{\text {b }}\end{array}$ & $\begin{array}{c}\text { Combined Rate/100,000 } \\
\text { (95\% CI) }\end{array}$ & $\begin{array}{c}\text { Combined Linear trend with } \\
\qquad \operatorname{APC}^{a}(95 \% C I)\end{array}$ \\
\hline 1975-79 & $\begin{array}{c}0.96 \\
(0.74,1.18)\end{array}$ & $\begin{array}{l}1975-81-6.27^{*} \\
(-11.23,-1.04)\end{array}$ & $\begin{array}{c}1.35 \\
(1.10,1.59)\end{array}$ & $\begin{array}{c}1975-1984-3.67^{*} \\
(-6.00,-1.28)\end{array}$ & $\begin{array}{c}1.53: 1 \\
(1.15,2.03)\end{array}$ & $\begin{array}{c}1.16 \\
(0.93,1.38)\end{array}$ & $\begin{array}{c}1975-1983 \\
-4.19^{*} \\
(-6.14,-2.19)\end{array}$ \\
\hline 1980-84 & $\begin{array}{c}0.77 \\
(0.58,0.95)\end{array}$ & $\begin{array}{l}1981-20011.98^{*} \\
(1.14,2.83)\end{array}$ & $\begin{array}{c}1.10 \\
(0.89,1.31)\end{array}$ & $\begin{array}{c}1984-20003.42^{*} \\
(2.43,4.42)\end{array}$ & $\begin{array}{c}1.54: 1 \\
(1.14,2.08)\end{array}$ & $\begin{array}{c}0.94 \\
(0.74,1.14)\end{array}$ & $\begin{array}{c}1983-2001 \\
2.77^{*} \\
(2.18,3.36)\end{array}$ \\
\hline $1985-89$ & $\begin{array}{c}0.86 \\
(0.68,1.05)\end{array}$ & & $\begin{array}{c}1.14 \\
(0.93,1.34)\end{array}$ & & $\begin{array}{c}1.44: 1 \\
(1.10,1.89)\end{array}$ & $\begin{array}{c}1.01 \\
(0.81,1.20)\end{array}$ & \\
\hline 1990-94 & $\begin{array}{c}0.96 \\
(0.77,1.15)\end{array}$ & & $\begin{array}{c}1.35 \\
(1.14,1.56)\end{array}$ & & $\begin{array}{c}1.57: 1 \\
(1.23,2.00)\end{array}$ & $\begin{array}{c}1.16 \\
(0.96,1.36)\end{array}$ & \\
\hline 1995-99 & $\begin{array}{c}1.04 \\
(0.85,1.23)\end{array}$ & & $\begin{array}{c}1.53 \\
(1.32,1.74)\end{array}$ & & $\begin{array}{c}1.67: 1 \\
(1.34,2.09)\end{array}$ & $\begin{array}{c}1.30 \\
(1.10,1.50)\end{array}$ & \\
\hline $2000-04$ & $\begin{array}{c}1.13 \\
(0.96,1.31)\end{array}$ & $\begin{array}{l}2001-2009-1.60 \\
(-3.88,0.74)\end{array}$ & $\begin{array}{c}1.69 \\
(1.49,1.90)\end{array}$ & $\begin{array}{c}2000-2009-0.93 \\
(-2.47,0.62)\end{array}$ & $\begin{array}{c}1.65: 1 \\
(1.36,2.02)\end{array}$ & $\begin{array}{c}1.43 \\
(1.23,1.62)\end{array}$ & $\begin{array}{c}2001-2009 \\
-1.69^{*} \\
(-3.02,-0.34)\end{array}$ \\
\hline 2005-09 & $\begin{array}{c}1.00 \\
(0.84,1.15)\end{array}$ & & $\begin{array}{c}1.63 \\
(1.44,1.82)\end{array}$ & & $\begin{array}{c}1.77: 1 \\
(1.46,2.14)\end{array}$ & $\begin{array}{c}1.33 \\
(1.15,1.50)\end{array}$ & \\
\hline Period & & $\begin{array}{l}\text { Linear trend with } A A P C^{c} \\
\quad(95 \% C I)\end{array}$ & & $\begin{array}{l}\text { Linear trend with } A A P C^{c} \\
\qquad(95 \% C I)\end{array}$ & & & $\begin{array}{l}\text { Linear trend with } A A P C^{c} \\
\qquad(95 \% C I)\end{array}$ \\
\hline Last 35 years & & $\begin{array}{c}-0.37 \\
(-1.51,0.79)\end{array}$ & & $\begin{array}{c}0.35 \\
(-0.51,1.20)\end{array}$ & & & $\begin{array}{c}0.04 \\
(-0.59,0.67)\end{array}$ \\
\hline
\end{tabular}

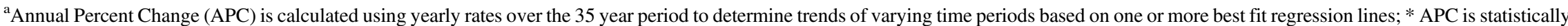
significantly different from $0(p<0.05)$.

${ }^{\mathrm{b}}$ Ratios based on crude mortality rates ${ }^{11}$.

${ }^{\mathrm{c}}$ Average Annual Percent Change (AAPC) is calculated using yearly rates over the 35 year period for an overall average; * AAPC is statistically significantly different from 0 ( $p<0.05$ ). 
(a)

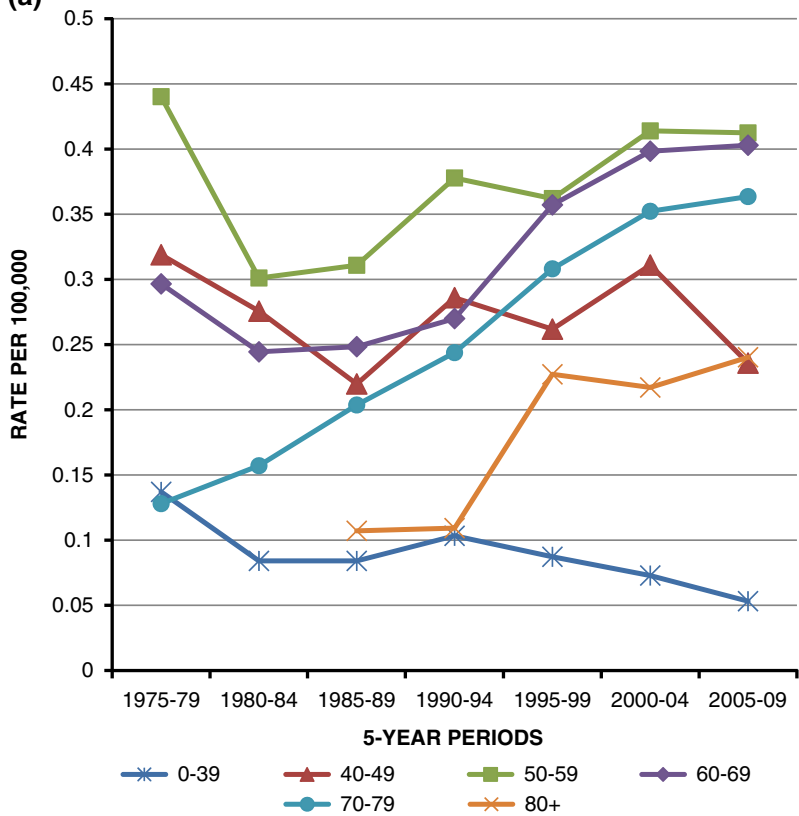

Figure 1(a): Age-standardized (Canada, 2006), female, average annual MS mortality rates per 100,000 population by five-year periods, 1975-2009, by age groups.

(b)

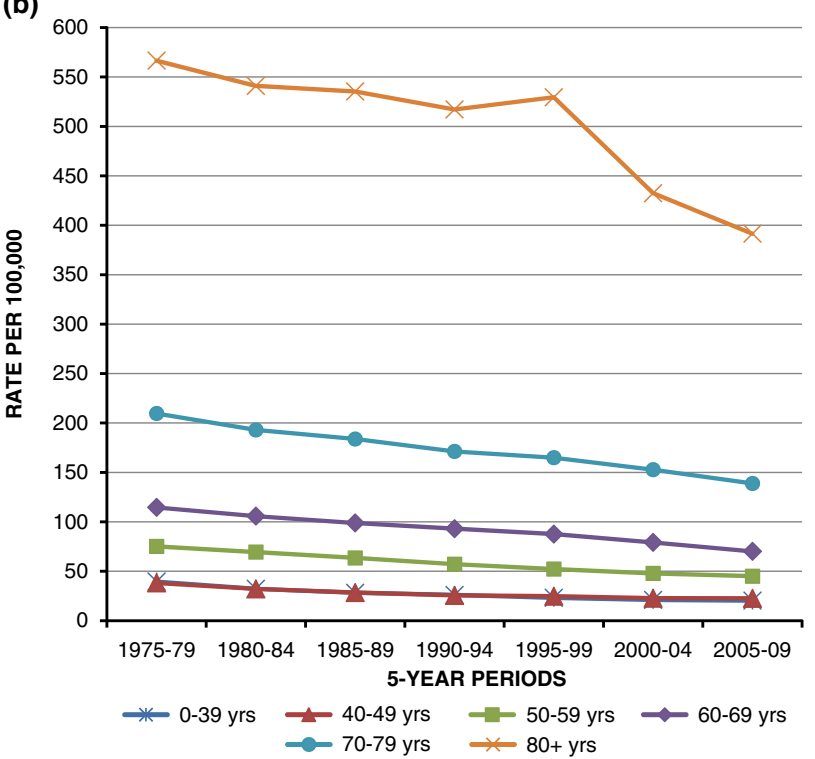

Figure 1(b): Age-standardized (Canada, 2006), female, average annual all causes mortality rates per 100,000 population by five-year periods, 1975-2009, by age groups.

Regardless of gender, trend analyses indicated a significant decrease in AAPC in the 0-39 year age group (male $=-2.53$; female $=-1.98$ ) and significant increases in the 60-69 $($ male $=1.17 ;$ female $=1.63), 70-79 \quad($ male $=2.30 ;$ female $=$ 3.34 ), and $80+$ age group (male $=2.44$; female $=5.40$ ) over the 35 -year span, indicating a slight shift to later age of death. This shift favoured females. The test of parallelism indicated stable female to male ratios across the majority of age categories. (a)

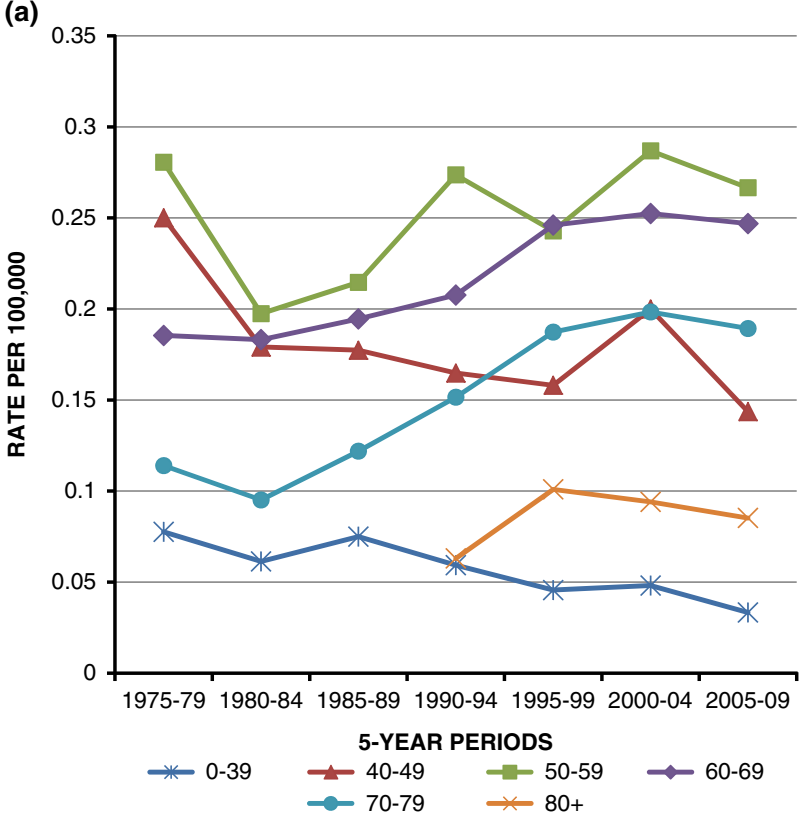

Figure 2(a): Age-standardized (Canada, 2006), male, average annual MS mortality rates per 100,000 population by five-year periods, 1975-2009, by age groups.

(b)

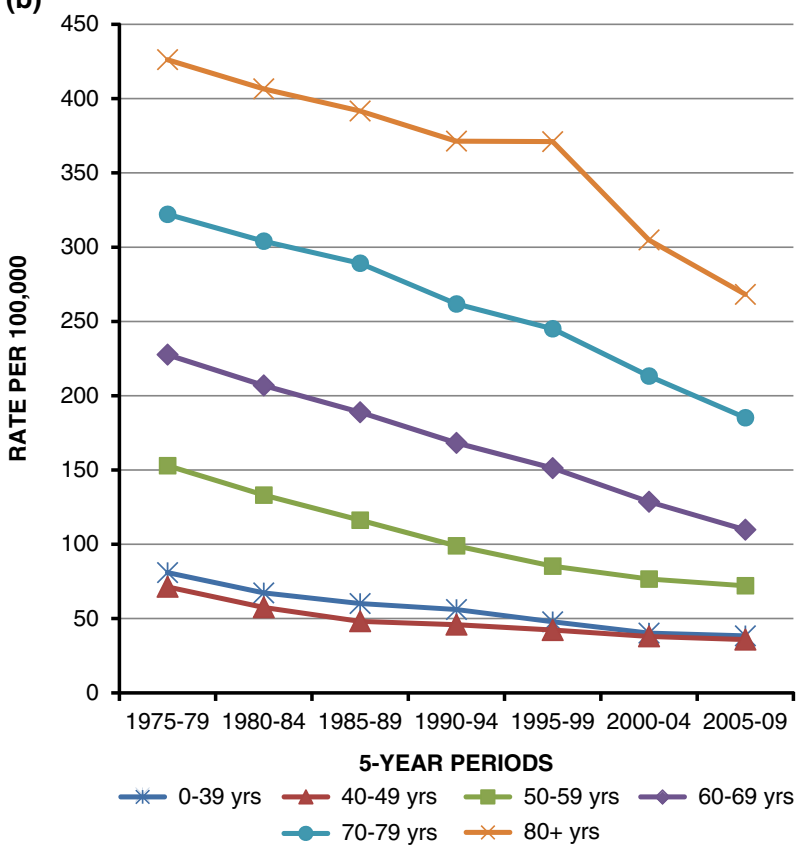

Figure 2(b): Age-standardized (Canada, 2006), male, average annual all causes mortality rates per 100,000 population by five-year periods, 1975-2009, by age groups.

The exception was the 70-79 age group, where the steady upward trend of the female MS mortality rate differed from the more variable male mortality rate.

Figures 1(b) and 2(b) show age-standardized and genderspecific average annual all-cause mortality rates in Canada for 
each five-year time period from 1975 to 2009 for females and males respectively. Trend analyses indicated that, regardless of gender, all age groups experienced slight but significant decreases over the 35 years. Decreases in AAPC were as follows: $0-39$ years age group male $=-2.47$, female $=-2.19 ; 40-49$ years male $=-2.30$, female $=-1.70 ; 50-59$ years male $=-2.33$, female $=-1.60 ; 60-69$ years male $=-2.37$, female $=-1.64$ ); $70-79$ years male $=-1.85$, female $=-1.49 ; 80+$ years male $=-1.53$, female $=-1.17$. There may have been some upward shift within the $80+$ years age category if it had been subdivided. In general over the 35-year span, the shift towards later age of death favoured males. The test of parallelism indicated that male to female trend lines were not parallel in any age group. Over time, the male and female mortality rates converged.

Figures 1(a) and 2(a) show that the highest MS mortality rates were consistently in the 50-59 years age group for both females and males, although these rates were not significantly different from the 40-49 and 60-69 years age groups through the 1980s for males and early 1990s for females. From the early to mid-1990s on rates in the 50-59 years age group tended to converge with those in the older age groups. For example, by $2005-09$, female rates in the $50-59,60-69$ and 70-79 years age groups were essentially equal at $0.41(0.32-0.51), 0.40(0.31-0.50)$ and $0.36(0.27-0.46)$ respectively; as were male rates in the 50-59, 60-69 and 70-79 years age groups at $0.27(0.09-0.35), 0.25(0.17-0.32)$ and 0.19 $(0.12-0.26)$. These results indicate a shift to later age at death for both females and males. As for all-cause mortality, Figures 1(b) and 2(b) show that the highest rates have been clearly in the $80+$ years age group for both females and males since the mid-1970s.

Table 2 shows the age-standardized combined average annual MS mortality rates by five-year time period from 1975 to 2009 and by geographic region with the results of the trend analysis. Similar to Canada overall, the trend lines indicated that rates have fluctuated with decreases and increases in the Western Provinces, Quebec and the Atlantic Provinces, although not always significant. The trend analyses indicated stable rates for these three regions over the 35-year time span (AAPCs of 0.25, 0.12 and -0.43 respectively). Only Ontario showed a significant but slight persistent increase over the 35 years $(\mathrm{AAPC}=0.81)$. Nevertheless, the test of parallelism for geographic region trend lines over the 35 years was not significant, indicating no differences. The increase in Ontario although significant was likely too slight to distinguish it from the other regions.

Table 3 shows the age-standardized, gender-specific and combined average annual MS mortality rates from 1975 to 2009 by geographic region, with the results of the trend analysis. The AAPCs for combined rates were stable within the regions over the 35-year time span, except for the slight average annual increase in Ontario. Within the Western Provinces there was an increase in male rates over the 35 -year time span, but female rates were stable. The reverse was seen in Ontario and the Atlantic Provinces, while rates were stable for Quebec. Female rates were consistently higher than male rates in each region, with the Western Provinces and Ontario showing significantly higher female rates according to the ratio CIs. The tests of parallelism for the female and male trend lines over time in each region as analyzed were not significant, indicating a consistent spread in the ratios over time.

\section{DisCUSSION}

The limitations of mortality rates have been extensively reviewed, including accuracy of death certificate diagnosis, differences in coding practices (e.g. primary, underlying, contributing cause or coexisting condition) and completeness of reporting over time and place. ${ }^{12}$ Nevertheless patterns observed from MS mortality rates have been shown to mirror those observed in more sophisticated study designs such as case-control studies, natural history cohorts and clinical trials which also have limitations. ${ }^{12,13}$ Consequently mortality rates are used in the literature as a proxy for incidence rates in the search for clues to MS etiology, to assess the possible impact of changes in health care and to predict the need for future services. A recent review of MS incidence and prevalence in the Americas ${ }^{14}$ concluded that more epidemiological studies need to be conducted on a national level using similar methods so that rates within and across countries are more comparable and allow examination of trends over a long period of time. Retroactive data on incidence meeting these criteria remains unavailable but the criteria have largely been met for mortality data in Canada by Statistics Canada.

\section{Comparison to Previously Reported Canadian MS Mortality Rates}

Since we had previously reported on MS mortality rates in Canada, 1965-1994, ${ }^{5}$ based on data provided by Statistics Canada through Alberta Health and Wellness, we decided to compare the findings for overlapping five-year periods in the two studies to determine whether there were any different observations with regard to trends over time. The age-standardized, gender-specific and combined average annual MS mortality rates observed in this study for the time periods covered by the previous study, that is, $1975-79,1980-84,1985-89,1990-94$, decrease and increase in the same pattern. Both studies indicate that Canadian mortality rates fluctuated but remained essentially stable between 1975 and 1994 . Female rates are consistently higher than male rates in both studies. As in this study, the age and gender-specific average annual mortality rates in the previous study indicate a shift towards later age of death. Time trends within geographic regions fluctuated in the same pattern, but remained essentially stable, in both studies.

MS mortality rates were higher in the previous study than in this one, although rates in both studies place Canada among the highest worldwide. Statistics Canada notes in its literature on use of their data that there can be differences in rates produced for several reasons, ${ }^{15}$ including definition of numerator, coding practices for cause of death, definition of denominator, populations at risk chosen, and populations used for age-standardization.

\section{Time Trends in MS Mortality}

Research has indicated that the incidence of MS is increasing in some countries, ${ }^{16}$ suggesting increased exposure to an environmental risk factor. To the extent that mortality rate patterns reflect incidence, the stable mortality rates observed in this study do not indicate that MS incidence is increasing in Canada and therefore support a stable risk factor(s), such as some type of virus, in its etiology. There have been changes in health care practices over the past 35 years, including treatment for specific MS symptoms such as urinary tract and pulmonary infections and immunosuppressive disease modifying drugs. Ostensibly these should have 


\begin{tabular}{|c|c|c|c|c|c|c|c|c|}
\hline Period & $\begin{array}{c}\text { Western Provinces Rate/ } \\
100,000(95 \% \text { CI) }\end{array}$ & $\begin{array}{l}\text { Linear trend with } \\
\text { APC }^{a}(95 \% \text { CI) }\end{array}$ & $\begin{array}{c}\text { Ontario Rate/ } \\
100,000(95 \% \text { CI) }\end{array}$ & $\begin{array}{l}\text { Linear trend with } \\
\operatorname{APC}^{a}(95 \% \text { CI) }\end{array}$ & $\begin{array}{c}\text { Quebec Rate/ } \\
100,000(95 \% \text { CI) }\end{array}$ & $\begin{array}{l}\text { Linear trend with } \\
\text { APC }^{a}(95 \% \mathrm{CI})\end{array}$ & $\begin{array}{c}\text { Atlantic Provinces Rate/ } \\
100,000(95 \% \text { CI) }\end{array}$ & $\begin{array}{l}\text { Linear trend with } \\
\text { APC }^{a}(95 \% \text { CI })\end{array}$ \\
\hline $1975-79$ & $\begin{array}{c}1.27 \\
(0.82,1.73)\end{array}$ & $\begin{array}{c}1975-1983-4.24 * \\
(-7.39,-0.98)\end{array}$ & $\begin{array}{c}1.03 \\
(0.67,1.36)\end{array}$ & $\begin{array}{c}1975-20090.81^{*} \\
(0.37-1.25)\end{array}$ & $\begin{array}{c}1.21 \\
(0.75,1.67)\end{array}$ & $\begin{array}{c}1975-1987-2.30^{*} \\
(-3.87,-0.70)\end{array}$ & $\begin{array}{c}1.19 \\
(0.40,1.98)\end{array}$ & $\begin{array}{c}1975-1980 \\
-12.45 \\
(-25.67,3.11)\end{array}$ \\
\hline $1980-84$ & $\begin{array}{c}1.04 \\
(0.65,1.44)\end{array}$ & $\begin{array}{c}1983-20022.73^{*} \\
(1.89,3.57)\end{array}$ & $\begin{array}{c}0.82 \\
(0.52,1.13)\end{array}$ & & $\begin{array}{c}1.01 \\
(0.61,1.41)\end{array}$ & & $\begin{array}{c}0.86 \\
(0.20,1.52)\end{array}$ & $\begin{array}{c}1980-2009 \\
1.80 * \\
(0.83,2.78)\end{array}$ \\
\hline $1985-89$ & $\begin{array}{c}1.08 \\
(0.70,1.46) \\
\end{array}$ & & $\begin{array}{c}0.98 \\
(0.67,1.30) \\
\end{array}$ & & $\begin{array}{c}1.00 \\
(0.61,1.39) \\
\end{array}$ & $\begin{array}{c}1987-19994.68^{*} \\
(3.01,6.37) \\
\end{array}$ & $\begin{array}{c}0.91 \\
(0.27,1.54) \\
\end{array}$ & \\
\hline $1995-99$ & $\begin{array}{c}1.36 \\
(0.99,1.73)\end{array}$ & & $\begin{array}{c}1.15 \\
(0.85,1.46)\end{array}$ & & $\begin{array}{c}1.47 \\
(1.05,1.89)\end{array}$ & $(-3.73,-0.80)$ & $\begin{array}{c}1.00 \\
(0.39,1.62)\end{array}$ & \\
\hline $2000-04$ & $\begin{array}{c}1.65 \\
(1.27,2.04) \\
\end{array}$ & $\begin{array}{c}2002-2009-1.05 \\
(-3.54,1.51) \\
\end{array}$ & $\begin{array}{c}1.19 \\
(0.90,1.48) \\
\end{array}$ & & $\begin{array}{c}1.52 \\
(1.12,1.92) \\
\end{array}$ & & $\begin{array}{c}1.26 \\
(0.61,1.90) \\
\end{array}$ & \\
\hline 2005-09 & $\begin{array}{c}1.57 \\
(1.22,1.92) \\
\end{array}$ & & $\begin{array}{c}1.16 \\
(0.90,1.43) \\
\end{array}$ & & $\begin{array}{c}1.36 \\
(1.00,1.72)\end{array}$ & & $\begin{array}{c}1.28 \\
(0.66,1.91)\end{array}$ & \\
\hline
\end{tabular}

${ }^{a}$ Annual Percent Change (APC) is calculated using yearly rates over the 35 year period to determine trends of varying time periods based on one or more best fit regression lines; * APC is statistically significantly different from $0(p<0.05)$.

${ }^{\mathrm{b}}$ Average Annual Percent Change (AAPC) is calculated using yearly rates over the 35 year period for an overall average; * AAPC is statistically significantly different from $0(p<0.05)$. $\mathrm{CI}=$ confidence interval. 
Table 3: Age-standardized (Canada, 2006), gender-specific and combined average annual MS mortality rates per 100,000 population, 1975-2009, by geographic region

\begin{tabular}{|c|c|c|c|c|c|c|c|}
\hline $\begin{array}{l}\text { Region of } \\
\text { Canada }\end{array}$ & $\begin{array}{l}\text { Males Rate/100 } \\
\mathbf{0 , 0 0 0}(\mathbf{9 5} \% \mathrm{CI})\end{array}$ & $\begin{array}{l}\text { Linear trend with } \\
\text { AAPC }^{a} \text { Last } 35 \text { yrs }\end{array}$ & $\begin{array}{c}\text { Females Rate/ } \\
100,000(95 \% \text { CI })\end{array}$ & $\begin{array}{l}\text { Linear trend with } \\
\text { AAPC }^{a} \text { Last } 35 \text { yrs }\end{array}$ & $\begin{array}{l}\text { Female to } \\
\text { Male Ratio }\end{array}$ & $\begin{array}{c}\text { Combined Rate/ } \\
100,000(95 \% \text { CI })\end{array}$ & $\begin{array}{l}\text { Linear trend with } \\
\text { AAPC }^{a} \text { Last } 35 \text { yrs }\end{array}$ \\
\hline $\begin{array}{l}\text { Western } \\
\text { Provinces }\end{array}$ & $\begin{array}{c}1.12 \\
(0.75,1.48)\end{array}$ & $0.88^{*}$ & $\begin{array}{c}1.64 \\
(1.22,2.06)\end{array}$ & 0.21 & $\begin{array}{c}1.60: 1 \\
(1.07,2.41)\end{array}$ & $\begin{array}{c}1.39 \\
(0.99,1.78)\end{array}$ & 0.27 \\
\hline Ontario & $\begin{array}{c}0.84 \\
(0.56,1.12)\end{array}$ & 0.50 & $\begin{array}{c}1.29 \\
(0.97,1.61)\end{array}$ & $0.97 *$ & $\begin{array}{c}1.71: 1 \\
(1.13,2.57)\end{array}$ & $\begin{array}{c}1.08 \\
(0.77,1.38)\end{array}$ & $0.81 *$ \\
\hline Quebec & $\begin{array}{c}1.08 \\
(0.69,1.48)\end{array}$ & -1.35 & $\begin{array}{c}1.49 \\
(1.07,1.91)\end{array}$ & 0.60 & $\begin{array}{c}1.55: 1 \\
(0.99,2.42)\end{array}$ & $\begin{array}{c}1.30 \\
(0.89,1.71)\end{array}$ & 0.12 \\
\hline $\begin{array}{l}\text { Atlantic } \\
\text { Provinces }\end{array}$ & $\begin{array}{c}0.86 \\
(0.26,1.46)\end{array}$ & -1.93 & $\begin{array}{c}1.28 \\
(0.59,1.98)\end{array}$ & $1.39 *$ & $\begin{array}{c}1.61: 1 \\
(0.69,3.75)\end{array}$ & $\begin{array}{c}1.09 \\
(0.43,1.74)\end{array}$ & -0.43 \\
\hline
\end{tabular}

${ }^{a}$ Average Annual Percent Change (AAPC); * AAPC is statistically significantly different from $0(p<0.05)$.

${ }^{\mathrm{b}}$ Ratios based on crude mortality rates as recommended ${ }^{11}$.

$\mathrm{CI}=$ confidence interval.

decreased mortality rates by extending duration of disease among MS patients. There is some indication that MS patients are living longer in parts of Canada, ${ }^{17}$ although this observation may be a consequence of earlier diagnosis following the introduction of tools such as magnetic resonance imaging. Shifts in age at death due to MS in this study are slight and new treatments may not yet have resulted in patients living long enough to die from other causes, such as cardiovascular diseases or cancer, either in Canada as a whole or its geographic regions.

\section{Gender-specific MS Mortality}

The higher MS mortality rates in females compared to males could be artifactual. For example, physicians may report MS more frequently on the death certificates of women because MS is known to be more common among them. However, the disease is often more severe in men and therefore more recognizable which should counterbalance this phenomenon. If the difference in female to male mortality rates is real, the higher rate in females could simply be due to the higher incidence of MS among females in Canada. ${ }^{18}$ The apparently unchanging female to male mortality rate ratios do not support the idea that incidence among females has been increasing more than among males over time as has been observed in some countries, ${ }^{16}$ nor the idea that exposure to some environmental risk factor is diverging between the genders. Care practices favouring men could result in lower mortality, but there does not appear to be any empirical evidence of a practice differential. Regardless, mortality due to MS does not appear to be decreasing among either women or men in Canada.

\section{Age-specific MS Mortality}

The shift in age of death to older years suggests that life expectancy may be increasing among MS patients due to diseasespecific therapies; and there is some supporting evidence that patients receiving early DMD treatment have a survival advantage over non-treated patients. ${ }^{19}$ It may also however be a reflection of extended life expectancy among the general population of Canada due to non-disease-specific improvements in health care, in lifestyle or the environment. It is difficult to separate out the effect of such variables on MS mortality, particularly since there have been no single DMD introductions that could be linked to a noticeable drop in mortality as in the example of chemotherapy for tuberculosis. ${ }^{20}$ More research specifically designed to examine the relative contribution of DMDs to other possible factors is needed. Despite the shift to later age of death among MS patients, most notably among women, both genders remain disadvantaged in comparison to the general population, where mortality rates remain substantially higher.

\section{Implications}

Long term studies are valuable in revealing patterns that may be misinterpreted if only shorter time periods are examined. For example, over the 35 years covered by this study, significant decreases, significant increases and stabilization were seen in Canadian MS mortality rates during specific sub-periods. Whether or how MS mortality is changing over time worldwide is debatable when the literature is taken as a whole. Rates have been reported as decreasing, increasing and remaining stable in various countries, which may be due to a protracted reporting period in some instances. However it does seem clear that MS prevalence is increasing worldwide, especially among women ${ }^{1}$ and there is some evidence that patients are living longer. ${ }^{21}$ Later age at death may result in more patients with notable disability since disability has been observed to increase with duration and it is not clear that new treatments like DMDs influence progression. ${ }^{22}$ Together these observations suggest that the need for health care services for persons with multiple sclerosis, particularly services tailored for the older age groups, women and notably disabled, will increase in Canada in the near future.

\section{ACKNOWLedgments}

The authors thank Fort Assiniboine Equine Endeavour Foundation, Alberta for financial support.

\section{Disclosures}

Sharon Warren, Wonita Janzen, Kenneth Warren, Lawrence Svenson, and Donald Schopflocher do not have anything to disclose.

\section{REFERENCES}

1. Warren S, Warren K. Multiple Sclerosis. World Health Organization, Geneva, 2001.

2. Lai SM, Zhang ZX, Alter M, et al. World-Wide Trends in Multiple Sclerosis Mortality. Neuroepidemiology. 1989;8:56-67. 
3. Ekestern E, Lebhart G. Mortality from multiple sclerosis in Austria 1970 to 2001: dynamics, trends, and prospects. Eur J Neurol. 2004;11:511-20.

4. Redelings MD, McCoy L, Sorville F. Multiple sclerosis mortality and patterns of comorbidity, in the United States from 1990 to 2001. Neuroepidemiology. 2006;26:102-7.

5. Warren S, Warren KG, Svenson LW, Schopflocher DP, Jones A. Geographical and temporal distribution of mortality rates for multiple sclerosis in Canada, 1965-94. Neuroepidemiology. 2003; 22:75-81.

6. Statistics Canada. Table 051-0001 - Estimates of population, by age group and sex for July 1, Canada, provinces and territories, annual (persons unless otherwise noted), CANSIM (database) [cited 2013 February 20]. Available from: http://www5.statcan.gc.ca/ cansim/pick-choisir?lang $=$ eng $\& p 2=33 \&$ id $=0510001$

7. IBM Corp: IBM SPSS Statistics for Windows, Version 20.0. Armonk, NY: IBM Corp; 2011.

8. Bains N. Standardization of Rates 2009 [cited 2013 January 30]. Available from: http://www.apheo.ca/resources/indicators/ Standardization\%20report_NamBains_FINALMarch16.pdf

9. JoinPoint Regression Program, v.4.0.4. Statistical Research and Applications Branch: National Cancer Institute, May 2013 [cited 2013 September 15]. Available from: http://surveillance.cancer. gov/joinpoint/

10. Graham PL, Mengersen K, Morton AP. Confidence limits for the ratio of two rates based on likelihood scores: noniterative method. Stat Med. 2003;22:2071-83.

11. Boyle P, Parkin DM. Statistical methods for registries. In: Jensen OM, Parkin DM, MacLennan R, Muir CS, Skeet RG. editors. Cancer registration: Principles and methods (IARC Scientific Publications No. 95). Lyon: IARC; 1991, p. 126-58.
12. Scalfari A, Knappertz V, Cutter G, Goodin DS, Ashton R, Ebers GC. Mortality in patients with multiple sclerosis. Neurology. 2013; 81:184-92.

13. Kurtzke JF, Lux WE Jr. In defense of death data: an example with multiple sclerosis. Neurology. 1985;35:1787-90.

14. Evans C, Beland SG, Kulaga S, et al. Incidence and prevalence of multiple sclerosis in the Americas: a systematic review. Neuroepidemiology. 2013;40:195-210.

15. Statistics Canada. Vital statistics - Deaths database [updated 2013 September 04; cited 2014 October 28]. Available from: http:// www23.statcan.gc.ca/imdb/p2SV.pl?Function=getSurvey\&SDDS $=$ 3233.

16. Koch-Hendriksen N, Sorensen PS. The changing demographic pattern of multiple sclerosis epidemiology. Lancet Neurol. 2010; 9:268-77.

17. Kingswell E, van der Kop M, Zhao Y, et al. Relative mortality and survival in multiple sclerosis: findings from British Columbia. J Neurol Neurosurg Psychiatry. 2012;83:61-6.

18. Sadovnick AD, Ebers GC. Epidemiology of multiple sclerosis: a critical overview. Can J Neurol Sci. 1993;20:17-29.

19. Goodin DS, Reder AT, Ebers GC, et al. Survival in MS. A randomized cohort study 21 years after the start of the pivotal IFN $\beta$-1b trial. Neurology. 2012;78:1315-22.

20. Stevens RG, Lee JA. Tuberculosis: generation effects and chemotherapy. Am J Epidemiol. 1978;107:120-6.

21. Tremlett H, Zhao Y, Rieckmann P, Hutchinson M. New perspectives in the natural history of multiple sclerosis. Neurology. 2010; 74:2004-15.

22. Katrych O, Simone TM, Azad S, Mousa SA. Disease-modifying agents in the treatment of multiple sclerosis: a review of long-term outcomes. CNS Neurol Disord Drug Targets. 2009;8:512-9. 